\title{
PENYELENGGARAAN PENDIDIKAN ISLAM JAMAN KLASIK (di Masa Rasulullah SAW dan Era Kekhalifahan)
}

\author{
Ali Mubin \\ alimubin1972@gmail.com \\ (Fakultas Agama Islam, Universitas Muhammadiyah Tangerang)
}

\begin{abstract}
Abstrak
Pola pendidikan Islam pada masa Rasulullah, khulafaur-rasyidin (Abu Bakar ashShiddiq, Umar bin Khattab, Usman bin Affan, Ali bin Abi Thalib), Bani Umayyah dan Bani Abbasiyah, yaitu pendidikan yang bermuatan nilai ruhiyah dan bersumber dari wahyu. Dalam tulisan ini pula memperlihatkan bahwa Islam telah melakukan reformasi yang sangat penting dalam perubahan peradaban manusia. Perubahan tersebut antara lain sistem kehidupan jahiliyah sudah berganti menjadi sistem kehidupan masyarakat Islam yang beradab dan berakhlak. Masyarakat dunia mempunyai peradaban dan kebudayaan yang sangat tinggi setelah mereka mengambil Islam sebagai way of life dalam sistem kehidupan mereka. Proses terjadinya reformasi yang menyebabkan kemajuan tersebut tidak pernah lepas dari usaha keras dalam bidang pendidikan Islam yang berorientasi ke depan. Salah satu usaha tersebut adalah berlangsungnya proses pendidikan yang sangat baik yang pernah dilakukan dan ditanamkan oleh Rasulullah, khulafaurrasyidin, bani Umayyah dan bani Abasiyah.
\end{abstract}

\section{Kata Kunci: Penyelenggaraan Pendidikan, Islam, Jaman Klasik}

\section{A. Latar Belakang Masalah}

Sejarah pendidikan Islam pada hakekatnya tidak terlepas dari sejarah Islam. Sejarah, dalam bahasa Arab disebut tarikh yang berarti keterangan yang telah terjadi di kalangannya pada masa yang telah lampau atau pada masa yang masih ada. ${ }^{1}$ Sejarah mengungkapkan peristiwaperistiwa masa silam, baik peristiwa sosial, politik, ekonomi, maupun agama dan budaya dari suatu bangsa, negara atau dunia.

Sejarah pendidikan Islam memberikan arah kemajuan dan dinamikanya yang pernah dialami sehingga pembangunan dan pengembangan itu tetap berada dalam kerangka pandangan yang utuh dan mendasar. Sejarah bukanlah peristiwa-

\footnotetext{
${ }^{1}$ Munawar Cholil, Kelengkapan Tarikh Nabi Muhammad SAW., (Jakarta: Bulan Bintang, 1969), h. 15
}

peristiwa, melainkan tafsiran peristiwaperistiwa itu, dan pengertian mengenai hubungan nyata dan tidak nyata, yang menjalin seluruh bagian serta memberinya dinamisme dalam waktu dan tempat. ${ }^{2}$ Secara garis besar, Harun Nasution membagi sejarah Islam dalam tiga periode, yaitu periode klasik, pertengahan dan modern. ${ }^{3}$

Pada uaraian ini kita akan mengkaji sejarah pendidikan Islam periode klasik dimulai sejak jaman rasulullah SAW., masa khulafaur-rasyidin (Abu Bakar ashShiddiq, Umar bin Khattab, Usman bin Affan, Ali bin Abi Thalib), masa Bani

\footnotetext{
${ }^{2}$ Sayyid Quthub, Konsepsi Sejarah dalam Islam, Terj. Nabhan Husein, (Jakarta: Al-amin, tt. h.), h. 18

${ }^{3}$ Harun Nasution, Pembaharuan dalam Islam, Sejarah Pemikiran dan Gerakan, (Jakarta: Bulan Bintang, 1975), h.11
} 
Umayyah dan Bani Abbasiyah. Kajian ini sangat penting, dengan alasan: Pertama, di era sekarang ini generasi muda khususnya kalangan inteletual muslim banyak yang tidak mengetahui sejarah pendidikan Islam yang sudah berkontribusi dalam perubahan peradaban umat manusia. Alasan Kedua, kajian ini bermaksud memperlihatkan bahwa pola pendidikan Islam berbeda dengan pendidikan barat. Lalu, dari segi apa saja perbedaan pola pendidikan tersebut? dan seperti apa pola penyelenggaraan pendidikan Islam pada masa itu? penulis akan membahasnya pada uraian berikut.

\section{B. Identifikasi Masalah}

Dalam penulisan ini penulis dapat mengidentifikasi beberapa hal sebagai berikut:

1. Sistem penyelenggaraan pendidikan Islam masa rasulullah SAW.

2. Sistem penyelenggaraan pendidikan Islam masa khulafaur-rasyidin (Abu Bakar ash-Shiddiq, Umar bin Khattab, Usman bin Affan, Ali bin Abi Thalib).

3. Sistem penyelenggaraan pendidikan Islam masa Bani Umayyah.

4. Pola Penyelenggaraan pendidikan Islam masa Bani Abbasiyah.

5. Perbandingan penyelenggaraan pendidikan Islam jaman Rasulullah dan jaman ke-khalifahan.

\section{Rumusan Masalah}

Secara garis besar rumusan masalah dalam tulisan ini sebagai berikut:

1. Bagaimana pola penyelenggaraan pendidikan Islam pada masa Rasulullah, khulafaur-rasyidin (Abu Bakar ash-Shiddiq, Umar bin Khattab, Usman bin Affan, Ali bin Abi Thalib)?

2. Seperti apa pola penyelenggaraan pendidikan Islam masa Bani Umayyah?
3. Bagaimana pula pola penyelenggaraan pendidikan Islam masa Bani Abbasiyah?

\section{Metodologi Penulisan}

Metode penulisan ini dengan melakukan studi kepustakaan yang bersifat objektif, sistematis, analitis dan deskriptif.

\section{E. Pembahasan}

\section{Pendidikan Islam Masa Rasulullah}

Pelaksanaan pembinaan pendidikan Islam pada jaman Nabi dapat dibedakan menjadi dua tahap, baik dari segi waktu dan tempat penyelenggaraan, maupun dari segi isi dan materi pendidikannya, yaitu : (1) tahap/fase Makkah, sebagai awal pembinaan pendidikan Islam, dengan Mekkah sebagai pusat kegiatannya, (2) tahap/fase Madinah, sebagai fase lanjutan pembinaan/pendidikan Islam dengan Madinah sebagai pusat kegiatannya. ${ }^{4}$

\section{a. Pendidikan Islam di Mekkah}

Pendidikan Islam terjadi sejak Nabi Muhammad diangkat menjadi Rasul Allah di Mekkah dan beliau sendiri sebagai gurunya. Nabi Muhammad SAW menerima wahyu yang pertama di Gua Hira di Mekkah pada tahun 610 M. Dalam wahyu itu termaktub ayat al-qur'an yang artinya: "Bacalah (ya Muhammad) dengan nama tuhanmu yang telah menjadikan (semesta alam). Dia menjadikan manusia dari segumpal darah. Bacalah, dan tuhanmu maha pemurah. Yang mengajarkan dengan pena. Mengajarkan kepada manusia apa yang belum diketahuinya. ${ }^{5}$

Pendidikan Islam mulai dilaksanakan Rasulullah setelah mendapat perintah dari Allah agar beliau menyeru kepada Allah, sebagaimana yang termaktub dalam AlQur'an surat Al-Mudatstsir ayat 1-7.

\footnotetext{
${ }^{4}$ Zuhairini, dkk., Sejarah Pendidikan Islam, (Jakarta: Bumi Aksara, Cet. ke-9, 2008), h. 14-18

${ }^{5}$ (QS. Al-'Alaq: 1-5)
} 
Dalam surat Al-Mudatstsir ini bahwa" bangun (menyeru)" berarti mengajak dan mengajak berarti mendidik. ${ }^{6}$ Adapun Bahan/materi pendidikan tersebut diturunkan secara berangsur-angsur, sedikit demi sedikit.

Setelah banyak orang memeluk Islam, lalu Nabi menyediakan rumah AlArqam bin Abil Arqam untuk tempat pertemuan sahabat-sahabat dan pengikutpengikutnya. ${ }^{7}$ Di tempat itulah pendidikan Islam pertama dalam sejarah pendidikan Islam. Di sanalah Nabi mengajarkan dasardasar atau pokok-pokok agama Islam kepada sahabat-sahabatnya dan membacakan wahyu-wahyu (ayat-ayat) Al-Qur'an kepada para pengikutnya serta Nabi menerima tamu dan orang-orang yang hendak memeluk agama Islam atau menanyakan hal-hal yang berhubungan dengan agama Islam. Bahkan disanalah Nabi beribadah (sholat) bersama sahabatsahabatnya. ${ }^{8}$

Dalam masa pembinaan pendidikan agama Islam di Mekkah Nabi Muhammad juga mengajarkan al Qur'an karena alQur'an merupakan inti sari dan sumber

${ }^{6}$ Hanun Asrohah, Sejarah Pendidikan Islam, (Jakarta: Bumi Aksara, 1997), h. 12. (Surat alMudatssir yang artinya: "Hai orang yang berselimut, bangunlah lalu berilah peringatan dan Tuhanmu, agungkanlah dan pakaianmu, bersihkanlah dan perbuatan dosa, tinggalkanlah. Dan jangan kamu memberi (dengan maksud) memperoleh balasan yang lebih banyak. Dan untuk memenuhi perintah Tuhanmu, bersabarlah".

${ }^{7}$ Setelah turunnya ayat dalam surat al-alaq (ayat 1-5) sebagai refresentasi perintah belajar, maka wahyu Allah berikutnya sebagai landasan perintah mengajar, yaitu surat al-Mudatssir ayat 17. Setelah turun ayat ini Rasulullah SAW. mulai mengajar para sahabatnya, hingga jumlah mereka yang belajar selama kurun waktu tiga tahun setelah kenabian sebanyak: 53 orang. Terdiri dari laki-laki: 43 dan wanita 10 orang. Nabi bersama mereka yang beriman belajar bertempat di rumah al-Arqam bin Abi al-Arqom.,

${ }^{8}$ H. Mahmud Yunus, Sejarah Pendidikan Islam, (Jakarta: PT. Raja Grafindo Persada, 2008), h. 6 pokok ajaran Islam. Disamping itu Nabi Muhamad SAW, mengajarkan tauhid kepada umatnya. Intinya pendidikan dan pengajaran yang diberikan Nabi selama di Makkah ialah pendidikan keagamaan dan akhlak serta menganjurkan kepada manusia, supaya mempergunakan akal pikirannya memperhatikan kejadian manusia, hewan, tumbuh-tumbuhan dan alam semesta seagai anjuran pendidikan 'aqliyah dan ilmiyah.

Secara sederhana, Pendidikan Islam yang dilakukan Nabi Muhammad di Mekkah merupakan prototype yang bertujuan untuk membina pribadi Muslim agar menjadi kader yang berjiwa kuat dan dipersiapkan menjadi masyarakat Islam, mubaligh dan pendidik yang baik. Pada periode ini dilakukan dengan 3 tahapan, yaitu: 1) Secara rahasia dan perorangan, 2) Secara terang-terangan dan 3) Pendidikan Islam untuk umum. Adapun materi yang disampaikan adalah tentang ketuhanan (tauhid) dan juga tentang Al Qur'an dan segala kandungannya.

\section{b. Pendidikan Islam di Madinah}

Berbeda dengan periode di Mekkah, pada periode Madinah Islam merupakan kekuatan politik. Ajaran Islam yang berkenaan dengan kehidupan masyarakat banyak turun di Madinah. Nabi Muhammad juga mempunyai kedudukan, bukan saja sebagai kepala agama, tetapi juga sebagai kepala Negara. Cara Nabi melakukan pendidikan Islam di Madinah adalah dengan pembinaan masyarakat baru menuju satu kesatuan sosial dan politik. Nabi Muhammad SAW mulai meletakkan dasar-dasar terbentuknya masyarakat yang bersatu padu secara intern (ke dalam), dan ke luar diakui dan disegani oleh

\footnotetext{
${ }^{9}$ Zuhairini, dkk., Sejarah Pendidikan Islam,
} 
masyarakat lainnya (sebagai satu kesatuan politik). Dasar-dasar tersebut adalah: ${ }^{10}$

1). Nabi Muhammad SAW., mengikis habis sisa-sisa permusuhan dan pertentangan antar suku, dengan jalan mengikat tali persaudaraan diantara mereka.

2). Untuk memenuhi kebutuhan seharihari, Nabi Muhammad menganjurkan kepada kaum Muhajirin untuk berusaha dan bekerja sesuai dengan pekerjaan masing-masing.

3). Untuk menjalin kerjasama dan saling menolong dalam rangka membentuk tata kehidupan masyarakat yang adil dan makmur, turunlah syari'at zakat dan puasa, yang merupakan pendidikan bagi warga masyarakat dalam tanggung jawab sosial.

4). Suatu kebijaksanaan yang sangat efektif dalam pembinaan dan pengembangan masyarakat baru di Madinah, adalah disyari'atkannya media komunikasi berdasarkan wahyu, yaitu shalat Jum'at yang dilaksanakan secara berjama'ah. ${ }^{11}$ Setelah itu, nabi mengadakan perjanjian dengan kaum Yahudi, penduduk Madinah. Yang berisi bahwa kaum Yahudi bersahabat dengan kaum muslimin, tolongmenolong, bantu-membantu, terutama bila ada serangan musuh terhadap Madinah. Inilah salah satu perjanjian persahabatan yang dilakukan oleh Nabi Muhammad SAW. ${ }^{12}$

5). Pendidikan sosial politik dan kewarganegaraan (Sospol dan Pkn).

${ }^{10}$ H. Mahmud Yunus, Sejarah Pendidikan Islam, h. 26

\footnotetext{
${ }^{11}$ Zuhairini, dkk., Sejarah Pendidikan Islam, h. 37

${ }^{12}$ H. Mahmud Yunus, Sejarah Pendidikan Islam, h. 16
}

\section{c. Kurikulum \& Metode Pendidikan Islam pada Masa Rasulullah SAW}

Kurikulum dalam pendidikan Islam, dikenal dengan kata manhaj yang berarti jalan yang terang yang dilalui oleh pendidik bersama anak didiknya untuk mengembangkan pengetahuan, keterampilan, dan sikap mereka. ${ }^{13}$ Selain itu, kurikulum juga dapat dipandang sebagai suatu program pendidikan yang direncanakan dan dilaksanakan untuk mencapai pendidikan. ${ }^{14}$ H.M. Arifin memandang kurikulum sebagai seluruh bahan pelajaran yang harus disajikan dalam proses kependidikan dalam suatu sistem institusional pendidikan. ${ }^{15} \mathrm{~S}$. Nasution menyatakan, ada beberapa penafsiran lain tentang kurikulum. Diantaranya: Pertama, kurikulum sebagai produk (hasil pengembangan kurikulum), Kedua, kurikulum sebagai hal-hal yang diharapkan akan dipelajari oleh siswa (sikap, keterampilan tertentu), dan Ketiga, kurikulum dipandang sebagai pengalaman siswa. $^{16}$

Pengertian kurikulum dalam pandangan modern merupakan program pendidikan yang disediakan oleh sekolah yang tidak hanya sebatas bidang studi dan kegiatan belajarnya saja, akan tetapi meliputi segala sesuatu yang dapat mempengaruhi perkembangan dan pembentukan pribadi siswa. ${ }^{17}$ Dalam hal ini proses pendidikan Islam bukanlah suatu proses yang dapat dilakukan secara

\footnotetext{
${ }^{13}$ Omar Mohammad al-Toumy al-Syaibany, Falsafah Pendidikan Islam, (Terj. Hasan Langgulung), (Jakarta: Bulan Bintang, 1984), h. 478

${ }^{14}$ Zakiyah Daradjat, dkk., Ilmu Pendidikan Islam, (Jakarta: Bumi Aksara, 1996), Cet. ke-3, h. 122

${ }^{15}$ H.M. Arifin, Ilmu Pendidikan Islam, (Jakarta: Bumi Aksara, 1991), h. 183

${ }^{16}$ S. Nasution, Asas-asas Kurikulum, (Jakarta: Bumi Aksara, 1994), Cet. ke-1, h. 5-9

${ }^{17}$ H. Ramayulis, Ilmu Pendidikan Islam, (Jakarta: Kalam Mulia, 2006), h. Cet.ke-5, h. 152
} 
serampangan, tetapi hendaknya mengacu kepada konseptualisasi manusia paripurna (insan kamil) yang strateginya telah tersusun secara sistematis dalam kurikulum pendidikan Islam. $^{18}$

Adapun kurikulum pendidikan Islam pada masa rasulullah memiliki cakupan materi sebagai berikut: Pertama, Kajian alQuran dan hadis mengenai keimanan, ibadah dan akhlaq. Kedua, materi tentang persatuan dan kesatuan, kesejahteraan sosial, gotong royong dan Hankam (Pertahanan dan Keamanan).

Sedangkan metode yang diterapkan dan dikembangkan oleh Nabi dalam menyampaikan materi yang ada yaitu: Metode ceramah, tanya jawab, demonstrasi, uswah (keteladanan) dan hafalan. ${ }^{19}$ Selain kurikulum dan metode, lembaga pendidikan masih sederhana yakni bertempat di rumah Rasul sendiri, rumah al-Arqam bin Abi Arqam, kuttab (rumah guru, halaman/pekarangan masjid) dan murid yang belajar di kuttab ini disebut dengan ashhabush shuffah. ${ }^{20}$ Menurut sebagian ahli, suffah ini dianggap sebagai universitas Islam pertama, the first Islamic university. ${ }^{21}$

\section{d. Kebijakan Rasulullah dalam Bidang Pendidikan}

Proses pendidikan pada jaman Rasulullah berada di Mekkah belum berjalan sebagaimana yang diharapkan. Hal yang demikian belum dimungkinkan, karena pada saat itu Nabi Muhammmad

152

${ }^{18}$ H. Ramayulis, Ilmu Pendidikan Islam, h.

${ }^{19}$ Armai Arief, Sejarah Pertumbuhan dan Perkembangan Lembaga Pendidikan Islam Klasik, (Bandung: Penerbit Angkasa, 2005), h. 135.

${ }^{20}$ Ashabus shuffah adalah orang-orang (sahabat) yang belajar di sudut-sudut masjid atau bilik-bilik yang berhubungan langsung dengan masjid, yang selanjutnya disebut shuffah.

${ }^{21}$ Moh. Untung Slamet, Muhammad Sang Pendidik, (Semarang: Pustaka Rizki Putera, 2005), h. 44 belum berperan sebagai pemimpin atau kepala Negara, bahkan beliau dan para pengikutnya berada dalam bayang-bayang ancaman pembunuhan kaum kafir Quraisy. Selama di Mekkah pendidikan berlangsung dari rumah ke rumah secara sembunyisembunyi. Setelah masyarakat Islam terbentuk di Madinah, barulah pendidikan Islam dapat berjalan dengan leluasa dan terbuka secara umum. Adapun kebijakan yang telah dilakukan Nabi Muhammad ketika di Madinah adalah:

1). Membangun masjid di Madinah. Masjid inilah yang selanjutnya digunakan sebagai pusat kegiatan pendidikan dan dakwah. ${ }^{22}$ Nabi Muhammad SAW juga memerintahkan beberapa sahabat seperti al-Hakam Ibn Sa'id untuk mengajar pada sebuah kuttab ketika Nabi Muhammad SAW berada di Madinah. ${ }^{23}$

2). Mempersatukan berbagai potensi yang semula saling berserakan bahkan saling

\footnotetext{
${ }^{22}$ Masjid pada masa permulaan Islam mempunyai fungsi yang jauh lebih bervariasi dibandingkan dengan fungsinya sekarang, karena selain mempunyai fungsi utama sebagai tempat pembinaan ketaqwaan dan beribadah, pembangunan masjid di Madinah oleh Nabi SAW. juga difungsikan sebagai tempat belajar. Di masjid pula nabi menyediakan tempat khusus bagi para sahabat beliau yang miskin yang kemudian dikenal dengan ahl-Shuffah. Mereka tinggal dan menetap di emperan masjid yang difungsikan sebagai "sekolah" untuk belajar membaca dan memahami agama. Di sana pula mereka mempelajari al-Quran kemudian melakukan rihlah (perjalanan ilmiah) ke seluruh penjuru dunia untuk mengajarkan al-Quran kepada umat manusia.

${ }^{23}$ Hasan Asari, Menyingkap Zaman Keemasan Islam, (Bandung: Mizan, 1994), h. 24. (Materi yang diajarkan di kuttab periode Madinah ini tidak jauh berbeda dengan yang diajarkan di Mekkah. Pelajaran baca-tulis menjadi materi pokok bagi pelajar yang ada di kuttab. Materi baca-tulis ini berkisar pada puisi dan pepatah-pepatah arab. Pelajaran membaca al-Quran tidak diberikan di kuttab, tetapi di Masjid dan di rumah-rumah. Namun begitu, seiring berjalannya waktu, maka alQuran juga diajarkan di kuttab.
} 
bermusuhan. Langkah ini dituangkan dalam dokumen yang lebih popular disebut piagam Madinah. Dengan adanya piagam tersebut terwujudlah keadaan masyarakat yang tenang, harmonis dan damai. ${ }^{24}$

Pada masa awal pendidikan Islam ini tentu saja pendidikan formal yang sistematis belum terselenggara dan pendidikan formal baru muncul pada masa belakangan yakni dengan kebangkitan madrasah. Permulaan pendidikan Islam bisa ditemukan di Mekah pada jaman Rasulullah. Nabi Muhammad menyiarkan konsep perubahan radikal, hubungan dan sikap masyarakat Arab yang menjadi mapan sampai saat ini. Perubahan itu sejalan dengan ajaran Islam yang memerlukan kreativitas baru secara kelembagaan untuk meneruskan kelangsungan dan perkembangan agama Islam. Nabi Muhammad berhasil membangkitkan kesadaran manusia terhadap pentingnya pengembangan bidang keilmuan atau pendidikan. $^{25}$

Jadi, pola pendidikan di masa Rasulullah SAW., intinya tidak terlepas dari metode, evaluasi, materi/kurikulum, peserta didik, lembaga, dasar dan tujuan pendidikan Islam, baik secara teoritis maupun praktis. ${ }^{26}$

${ }^{24}$ H. Abuddin Nata, Pendidikan Islam Perspektif Hadis, (Ciputat, UIN Jakarta Press, 2005), h. 24

${ }^{25} \mathrm{Hal}$ ini senada dengan pendapatnya Goege Makdisi dalam The Rise of Colleges Institutions of Learning in Islam and West, (Eidenburgh University Press, 1981), h.21

${ }^{26}$ M. Zainuddin, Paradigma Pendidikan Islam Holistik, (Jurnal: Ulumuna, Vol. XV, Nomor 1 Juni 2011). Lihat dalam http://www.iainmataram.ac.id. (Untuk mewujudkan pendidikan yang holistik wilayah pertama yang perlu direformasi adalah visi atau kerangka konseptual pendidikan secara menyeluruh. Pendidikan bermula dari prinsip tauhid (keutuhan dan keterpusatan pada Tuhan). Hal inilah yang menjadi dasar pijakan dalam pandangan dunia pendidikan. Prinsip tauhid mencakup konsep
2. Pendidikan Islam Masa Khulafaurrasyidin

a. Masa Abu Bakar as-Shiddiq (632634 M.)

Pola pendidikan Islam pada masa Khalifah Abu Bakar as-Shiddiq, masih seperti pada masa rasulullah SAW., baik dari segi materi maupun lembaga pendidikannya.

Dari segi materi pendidikan Islam terdiri dari pendidikan tauhid atau keimanan, akhlak, ibadah, kesehatan. Pendidikan keimanan yaitu, menanamkan bahwa satu-satunya yang wajib disembah adalah Allah SWT. Pendidikan akhlak, contohnya: adab masuk rumah orang, sopan santun bertetangga, bergaul dalam masyarakat. Pendidikan ibadah seperti pelaksanaan sholat, puasa dan haji. Sedangkan pendidikan kesehatan tentang kebersihan, bersuci, wudhu, tatacara mandi dan istinja, serta gerakan-gerakan dalam sholat merupakan didikan untuk memperkuat jasmani dan rohani.

\section{b. Masa Umar Ibn Khattab (634-644 M)}

Kebijakan penting berkaitan dengan pendidikan yang dikeluarkan Umar bin Khattab yaitu membuat surat tugas yang ditujukan kepada para panglima perangnya adalah, apabila mereka berhasil menguasai satu kota, hendaknya mereka mendirikan masjid sebagai tempat ibadah dan pendidikan. $^{27}$ Selain itu, beliau juga mengangkat dan menunjuk guru-guru untuk tiap-tiap daerah yang ditaklukkan itu, mereka bertugas mengajarkan isi AlQur'an dan ajaran Islam lainnya seperti Fiqih, Tauhid, Akhlak, dan Ibadah, kepada

filosofis maupun metodologis yang terstruktur dan koheren terhadap pemahaman kita terhadap dunia dan seluruh aspek kehidupan. Tauhid mengajarkabn kita untuk menghimpun pandangan holistic, terpadu dan komprehensif terhadap pendidikan.

${ }^{27}$ Samsul Nizar, Sejarah Pendidikan Islam, (Jakarta: Kencana Prenada Media Grup, 2009), h.47 
penduduk yang baru masuk Islam. $^{28}$ Diantara sahabat-sahabat yang ditunjuk oleh Umar bin Khattab ke daerah adalah Abdurahman bin Ma'qaal dan Imran bin Hashim. Kedua orang ini ditempatkan di Basyrah, Abdurrahman bin Ghanam dikirim ke Syiria dan Hasan bin Abi Jabalah dikirim ke Mesir. Dan dalam pembelajarannya mereka menggunakan metode halaqah (guru duduk di halaman masjid sedangkan murid-murid melingkarinya).

Sedangkan kurikulum pendidikan pada masa Umar bin Khattab, berisi tentang: pelajaran membaca dan menulis, menghafal al-Quran, hadis serta belajar pokok-pokok agama Islam. Pendidikan pada masa ini lebih maju dibandingkan sebelumnya. Pada masa ini tuntutan untuk belajar bahasa Arab, juga sudah mulai tampak, orang yang baru masuk Islam dari daerah yang ditaklukkan harus belajar bahasa Arab jika ingin belajar dan memahami pengetahuan Islam. Oleh karena itu, pada masa ini sudah ada pengajaran bahasa Arab. Oleh karena itu, pelaksanaan pendidikan lebih mapan karena selama pemerintahan Umar, negara berada dalam keadaan stabil dan aman, hal ini disebabkan telah ditetapkannya masjid sebagai pusat pendidikan, juga telah terbentuknya pusat-pusat pendidikan Islam di berbagai kota dengan berbagai materi pendidikan yang dikembangkan.

\section{c. Masa Usman bin Affan (644-656 M )}

Pada masa khalifah Usman bin Affan, pelaksanaan pendidikan tidak jauh berbeda dengan masa sebelumnya. Pendidikan di masa ini hanya melanjutkan apa yang telah ada, dan hanya sedikit terjadi perubahan yang mewarnai pendidikan Islam. Para sahabat yang

\footnotetext{
${ }^{28}$ Masa Umar inilah awal mula terbentuknya guru melalui pengangkatan oleh khalifah. Mereka juga digaji oleh Bendahara Negara (Baitul mal).
}

berpengaruh dan dekat dengan Rasulullah yang tidak diperbolehkan meninggalkan Madinah dimasa khalifah Umar, diberikan kelonggaran untuk keluar dan menetap di daerah-daerah yang mereka sukai. Kebijakan ini sangat besar pengaruhnya bagi pelaksanaan pendidikan di daerahdaerah. $^{29}$ Proses pelaksanaan pola pendidikan pada masa Usman ini lebih ringan dan lebih mudah dijangkau oleh seluruh peserta didik yang ingin menuntut dan belajar Islam. Dari segi pusat pendidikan juga lebih banyak, sebab pada masa ini para guru bisa memilih tempat yang mereka inginkan untuk memberikan pendidikan kepada masyarakat. Peserta didik pada masa ini terdiri dari: Orang dewasa dan atau orang tua yang baru masuk Islam, anak-anak, baik orang tuanya telah lama memeluk Islam ataupun yang baru memeluk Islam, Orang dewasa dan atau orang tua yang telah lama memeluk Islam dan Orang yang mengkhususkan dirinya menuntut ilmu agama secara luas dan mendalam.

Dari keempat golongan peserta didik tersebut, pelaksanaan pendidikan dan pengajaran tidak mungkin dilakukan dengan cara menyamaratakan tetapi harus diadakan pengklasifikasian yang rapi dan sistematis, disesuaikan dengan kemampuan dan kesanggupan dari peserta didiknya. Adapun metode yang digunakan adalah: Golongan pertama menggunakan metode ceramah, hafalan dan latihan. Golongan kedua menggunakan metode hafalan dan latihan. Golongan ketiga menggunakan metode diskusi, ceramah, hafalan dan tanya jawab. Golongan keempat menggunakan metode ceramah, hafalan tanya jawab dan diskusi serta sedikit hafalan. $^{30}$

\footnotetext{
${ }^{29}$ Samsul Nizar, ....h.48

${ }^{30}$ Soekarno, Sejarah dan Filsafat Pendidikan Islam, (Bandung: Angkasa, 1983), h. 60
} 


\section{d. Masa Ali bin Abi Thalib (656-661 M.) \\ Pada masa pemerintahan Ali bin Abi} Thalib, sudah diguncang peperangan dengan Aisyah (istri Nabi) beserta Talhah dan Abdullah bin Zubair karena kesalahfahaman dalam menyikapi pembunuhan terhadap Usman. Peperangan diantara mereka disebut perang Jamal (unta) karena Aisyah menggunakan kendaraan unta. Setelah berhasil mengatasi pemberontakan Aisyah, muncul pemberontakan lain, sehingga masa kekuasaan khalifah Ali tidak pernah mendapatkan ketenangan dan kedamaian. ${ }^{31}$

Diantara pemberontakan yang lain adalah dari Muawiyah sebagai gubernur Damaskus memberontak untuk menggulingkan kekuasaannya. Peperangan ini disebut perang Shiffin, karena terjadi di Shiffin. Ketika tentara Muawiyah terdesak oleh pasukan Ali, maka Muawiyah segera mengambil siasat untuk menyatakan tahkim (penyelesaian secara adil dan damai). Semula Ali menolak, tetapi karena desakan dari beberapa tentaranya akhirnya Ali menerimanya, namun tahkim malah menimbulkan kekacauan, sebab Muawiyah curang, dengan tahkim tersebut, Muawiyah berhasil mengalahkan Ali dan mendirikan pemerintahan tandingan di Damaskus. Sementara itu, sebagian tentara yang menentang keputusan Ali dengan cara tahkim, meninggalkan Ali dan membuat kelompok tersendiri yaitu khawarij. Dengan kericuhan politik pada masa Ali ini, kegiatan pendidikan Islam mendapat hambatan dan gangguan. Pada saat itu khalifah Ali bin Abi Thalib tidak lagi memikirkan masalah pendidikan karena seluruh perhatiannya ditumpahkan pada masalah keamanan dan kedamaian bagi masyarakat Islam.

Akhirnya dapat dikatakan bahwa, secara umum pola pendidikan pada masa

\footnotetext{
${ }^{31}$ Soekarno,....h. 50
}

Khulafaur rasyidin tidak jauh berbeda dengan masa Nabi yang menekankan pada pengajaran baca tulis dan materi tentang ajaran-ajaran Islam yang bersumber pada Al-Qur'an dan Hadits Nabi. Adapun kemajuan pendidikan yang dicapai pada masa Khulafaur-rasyidin yaitu terwujudnya pusat-pusat pendidikan antara lain: ${ }^{32}$

1). Mekkah. Guru pertama di Mekkah adalah Muaz bin Jabal yang mengajarkan Al-Qur'an dan Fiqih.

2). Madinah. Sahabat yang terkenal antara lain Abu Bakar, Usman bin Affan, Ali bin Abi Thalib, dan sahabat-sahabat lainnya.

3). Bashrah. Sahabat yang termasyhur antara lain Abu Musa Al-Asy'ari, seorang ahli fiqih dan Al-Qur'an.

4). Kuffah. Sahabat-sahabat yang termasyhur disini adalah Ali bin Abi Thalib dan Abdullah bin Mas'ud yang mengajarkan Al-Qur'an (ia adalah ahli tafsir, hadits dan fiqih).

5). Damsyik (Syam); sahabat yang mengajarkan ilmu di sana adalah Mu'az bin Jabal (di Palestina), Ubaidillah (di Hims) dan Abu Darda (di Damsyik).

6). Mesir. Sahabat yang mula-mula mendirikan madrasah dan menjadi guru di Mesir adalah Abdullah bin Amru bin Ash, ia adalah seorang ahli hadits.

\section{Pendidikan Islam Masa Bani Umayyah (41-132 H.)}

a. Visi, Misi, Tujuan, dan Sasaran

Visi pendidikan di jaman Bani Umayyah secara eksplisit tidak dijumpai. Namun dari berbagai petunjuk bisa diketahui bahwa visinya adalah unggul dalam ilmu agama dan umum sejalan dengan kebutuhan zaman dan masingmasing wilayah Islam. ${ }^{33}$

\footnotetext{
${ }^{32}$ Soekarno,....h. 51

${ }^{33}$ Abuddin Nata, Sejarah Pendidikan Islam, (Jakarta: Kencana), h. 131
} 
Adapun misinya antara lain: ${ }^{34}$

1). Menyelenggarakan pendidikan agama dan umum secara seimbang,

2). Melakukan penataan kelembagaan dan aspek-aspek pendidikan Islam,

3). Memberikan pelayanan pendidikan pada seluruh wilayah Islam secara adil dan merata,

4). Menjadikan pendidikan sebagai penopang utama kemajuan wilayah Islam,

5). Memberdayakan masyarakat agar dapat memecahkan masalahnya sesuai dengan kemampuanya sendiri.

Sedangkan tujuannya ialah menghasilkan sumber daya manusia yang unggul secara seimbang dalam ilmu agama dan umum serta mampu menerapkannya bagi kemajuan wilayah Islam. ${ }^{35}$ Dan yang menjadi sasarannya adalah seluruh umat atau warga yang terdapat di seluruh wilayah kekuasaan Islam, sebagai dasar bagi dirinya demi terciptanya masa depan yang lebih baik.

Visi, misi, tujuan, dan sasaran pendidikan tersebut di atas, secara eksplisit atau tertulis tentu belum ada. Namun dari segi kebijakannya secara umum serta hasilhasil yang dicapai oleh dinasti ini mengandung visi, misi, tujuan, dan sasaran tersebut di atas.

Sejarah mencatat, dinasti Umayyah telah mengeluarkan kebijakan dalam halhal sebagai berikut: ${ }^{36}$

a). Melakukan pemisahan antara kekuasaan agama dan kekuasaan politik, sehingga terjadi semacam dikotomi, namun bukan dalam hal ilmu agama dan ilmu umum.

b). Melakukan pembagian kekuasaan kedalam bentuk provinsi, yaitu Syiria dan Palestina, Kuffah, Irak, Basrah,

\footnotetext{
${ }^{34}$ Abuddin Nata,...,h. 131- 132

${ }^{35}$ Abuddin Nata,....h.132

${ }^{36}$ Badri Yatim, Sejarah Peradaban Islam, (Jakarta: Rajawali Press, 2011), h. 48-49
}

Persia, Sijistan, Khurasan, Bahrain, Oman, Najd, Yamah, Armenia, Hijaz, Karman dan India, Mesir, Afrika, Yaman, Arab Selatan, serta Andalusia.

c). Membentuk organisasi dan lembagalembaga pemerintahan dalam bentuk departemen, seperti dewan alKahawarij yang mengurusi pajak, dewan rasail yang menangani pos, dewan musghilat yang menangani kepentingan umum, dan dewan alhatim yang menangani dokumen negara.

d). Membentuk organisasi keuangan yang terpusat pada Baitul Mal yang diproleh dari pajak tanah, perorangan, dan nonmuslim, serta mencetak mata uang.

e). Membentuk organisasi ketentaraan yang umumnya terdiri dari orang-orang keturunan Arab.

f). Membentuk organisasi kehakiman.

g). Membentuk lembaga sosial dan budaya.

h). Membentuk bidang seni rupa seperti seni ukur, seni pahat dan kaligrafi.

i). Membentuk lembaga arsitektur, sebagaimana terlihat pada arsitektur kubah al-Sakhra di Baitul Maqdis, yaitu kubah batu yang didirikan pada masa khalifah Abdul Malik ibn Marwan pada tahun $691 \mathrm{M}$.

\section{b. Kurikulum}

Kurikulum pendidikan pada masa Bani Umayyah meliputi: ${ }^{37}$

1). Ilmu agama: al-Qur'an, Hadits dan Fiqih.

2). Sejarah dan Geografi.

3). Ilmu bahasa, yaitu segala ilmu yang mempelajari bahasa, nahwu, sharaf.

4). Ilmu filsafat, mantiq, kimia, astronomi, ilmu hitung dan ilmu kedokteran.

\section{c. Kelembagaan}


Lembaga-lembaga pendidikan yang berkembang pada masa Bani Umayyah, selain masjid, kuttab dan rumah sebagaimana yang telah ada sebelumnya, juga ditambah dengan lembaga pendidikan seperti Istana (kediaman sultan), Badiah (tempat pendidikan bahasa arab di wilayah Badui), Perpustakaan, Al-Bimaristan (ruang rumah sakit yang dijadikan tempat magang bagi para pelajar muslim), Kuttab (teras masjid), Masjid dan Majelis Sastra (pengembangan bangunan masjid). ${ }^{38}$

\section{Pendidikan Islam Masa Bani Abbasiyah (132-656 H.)}

Beberapa kemajuan dalam berbagai bidang kehidupan termasuk bidang pendidikan dapat disebutkan sebagai berikut: ${ }^{39}$

\section{a. Bidang Ilmu Agama}

Kemajuan pendidikan di bidang ilmu agama antara lain: Ilmu fiqih (lahirnya para ahli fiqh seperti:1) Imam Abu Hanifah (700-767 M), 2) Imam Malik (713-795 M), 3) Imam Syafi'i (767-820 M), 4) Imam Ahmad bin Hambal (780-855 M). Ilmu tafsir (munculnya para mufassir seperti: Ibnu Jarir Ath-Thabari, Ibnu Athiyah AlAndalusi, Abu Muslim Muhammad bin Bahar Isfahani). Ilmu hadis (ditandai dengan lahirnya para ahli hadis seperti: Imam Bukhori (194-256 H), karyanya Shahih Al-Bukhori, Imam Muslim (w. 261 H), karyanya Sahih Muslim, Ibnu Majah, karyanya Sunan Ibnu Majah, Abu Dawud, karyanya Sunan Abu Dawud, Imam AnNasai, karyanya Sunan An-Nasai, Imam Baihaqi).

\section{b. Bidang Ilmu Umum}

\footnotetext{
${ }^{38}$ Abuddin Nata, Sejarah Pendidikan Islam, (Jakarta: Kencana), h. 135-137, Soekarno dan Ahmad Supardi, Sejarah dan Filsafat Pendidikan Islam, (Bandung: Angkasa), h. 78-82

${ }^{39}$ http://riffai47.blogspot.co.id/2015: Sejarah Pendidikan Islam Masa Dinasti Abbasiyah, 8 November 2015.
}

Dalam bidang ilmu umum antara lain berkembang ilmu filsafat (tokohnya Ya'kub bin Ishaq al-Kindi), ilmu matematika (tokohnya yaitu alKhawarizmi), ilmu geografi (Ibn Khardazabah), ilmu kedokteran (Ibn Sina). ${ }^{40}$

\section{c. Bidang Teknologi}

Pada tahun 765, fakultas kedokteran pertama didirikan oleh Jurjis Ibnu Naubakh. Sekitar tahun 990 M, Ibnu Firnas seorang ilmuwan dari Andalusia (Spanyol) memimpikan bagaimana agar suatu saat manusia bisa terbang bebas di angkasa laksana burung, dia terinspirasi kejadian Isra' Mi'raj Nabi Muhammad SAW, tetapi dia berpikir bahwa manusia biasa tak mungkin bisa naik Bouraq kendaraan Nabi SAW untuk Isra' Mi' raj, karena dia hanya manusia biasa, bukan seorang Nabi. Ibnu Firnas (Armen Firman), mulai meneliti gerak aerodinamika, fisika udara, dan anatomi burung dan kelelawar. Sampai pada suatu saat dia menciptakan sebuah alat terbang seperti sayap kelelawar, lalu dia menaiki menara Masjid Cordoba, disaksikan oleh ribuan orang di bawahnya, lalu dia melompat dan melayang terbang sejauh kira-kira $3 \mathrm{~km}$ dan mendarat dengan selamat. Ribuan orang bertepuk tangan atas ciptaannya. Sebaliknya masyarakat Eropa yang saat itu sedang di era kegelapan, heboh sendiri karena menganggap Ibnu Firnas melakukan sihir yang mereka saja belum pernah melihatnya. Alat terbang Ibnu Firnas inilah yang menginspirasi Wright Bersaudara menciptakan pesawat terbang pada awal abad $19 .{ }^{41}$

\footnotetext{
${ }^{40}$ Samsul Munir Amin, Sejarah Peradaban Islam, (Jakarta: Amzah, 1992), h. 138

${ }^{41}$ http://riffai47.blogspot.co.id/2015: makalah Sejarah Pendidikan Islam Masa Dinasti Abbasiyah, 2015
} 


\section{Visi, Misi, Tujuan Pendidikan Islam} Masa Abbasiyah

Pada masa Nabi, masa kholifah alRasyidin dan umayah, Visi, Misi dan Tujuan pendidikan masih seirama, yaitu penguasaan bidang keagamaan semata. Nah, ada sedikit perbedaan tujuan pendidikan di masa Abbasiyyah bahwa tujuan pendidikan telah bermacam-macam karena pengaruh masyarakat pada masa itu. Tujuan itu dapat disimpulkan sebagai berikut:

1. Menguasai ilmu keagamaan dan memiliki akhlak yang mulia.

2. Agar mampu bermasyarakat dengan baik yakni Para pemuda pada masa itu belajar dan menuntut ilmu supaya mereka dapat mengubah dan memperbaiki masyarakat, dari masyarakat yang penuh dengan kejahilan menjadi masyarakat yang bersinar ilmu pengetahuan.

3. Menguasai ilmu pengetahuan dalam berbagai bidang.

4. Memperoleh kehidupan yang lebih layak, seperti mendapatkan pangkat yang tinggi dan bahkan mendapat kemegahan dalam kehidupan di dunia

\section{Lembaga-Lembaga Pendidikan Islam Masa Bani Abbasiyyah}

Pada masa Bani Abbasiyyah lembaga pendidikan/sekolah terdiri dari beberapa tingkat, yaitu:

1. Tingkat sekolah rendah, namanya kuttab (sebagai tempat belajar bagi anak-anak). Disamping kuttab ada pula anak-anak belajar di rumah, di istana, di toko-toko dan di pinggir-pinggir pasar.

2. Tingkat sekolah menengah, yaitu di masjid dan majelis sastra dan ilmu pengetahuan sebagai sambungan pelajaran di kuttab.
3. Tingkat Perguruan Tinggi, seperti Baitul Hikmah di Bagdad dan Darul Ilmu di Mesir (Kairo).

4. Toko-toko Buku. Pada masa ini, toko buku berkembang dengan pesat seiring dengan pesatnya perkembangan ilmu pengetahuan. Toko buku ini tidak hanya menjadi pusat pengumpulan dan penjualan buku-buku, tetapi juga menjadi pusat pendidikan.

5. Madrasah. Madrasah yang pertama didirikan adalah madrasah alBaehaqiyah di kota Naisabur. Dan juga perdana menteri Nizam al-Muluk mendirikan madrasah an-Nizamiyah. Pendirian beberapa madrasah ini dilatarbelakangi karena masjid-masjid telah dipenuhi oleh pengajianpengajian dari para guru yang semakin banyak, sehingga mengganggu orang yang sedang shalat.

\section{Kurikulum Pendidikan Islam Masa Bani Abbasiyah}

Kurikulum yang dikembangkan dalam pendidikan Islam saat itu, yaitu:

Pertama, kurikulum pendidikan tingkat dasar yang terdiri dari pelajaran membaca, menulis, tata bahasa, hadis, prinsip-prinsip dasar Matematika dan pelajaran syair. Ada juga yang menambahnya dengan mata pelajaran nahwu dan cerita-cerita. Ada juga kurikulum yang dikembangkan sebatas menghapal Al-Quran dan mengkaji dasar-dasar pokok agama. Kedua, kurikulum pendidikan tinggi. Pada pendidikan tinggi, kurikulum sejalan dengan fase dimana dunia Islam mempersiapkan diri untuk memperdalam masalah agama, menyiarkan dan mempertahankannya. Akan tetapi bukan berarti pada saat itu, yang diajarkan melulu agama, karena ilmu yang erat kaitannya dengan agama seperti bahasa, sejarah, tafsir dan hadis juga diajarkan. 
Metode Pendidikan Islam Masa Bani Abbasiyah

Pada masa Bani Abbasiyah metode pendidikan/pengajaran yang digunakan dapat dikelompokkan menjadi tiga macam: lisan, hafalan, dan tulisan.

1. Metode Lisan; berupa dikte, ceramah, qira'ah dan diskusi. Metode dikte (imla') adalah metode penyampaian pengetahuan yang dianggap baik dan aman karena dengan imla' ini murid mempunyai catatan yang akan dapat membantunya ketika ia lupa. Metode ini dianggap penting, karena pada masa klasik buku-buku cetak seperti masa sekarang sulit dimiliki. Sedangkan metode Metode ceramah disebut juga metode as-sama' (mendengarkan) yakni guru menjelaskan isi buku dengan hafalan, sedangkan murid mendengarkannya. Metode qiro'ah biasanya digunakan untuk belajar membaca sedangkan diskusi merupakan metode yang khas pada masa ini.

2. Metode Menghafal, yang merupakan ciri umum pendidikan pada masa ini. Murid-murid harus membaca secara berulang-ulang pelajarannya sehingga pelajaran tersebut melekat pada benak mereka, sebagaimana yang dijelaskan oleh Imam Hanafi, seorang murid harus membaca suatu pelajaran berulang kali sampai dia menghafalnya. Sehingga dalam proses selanjutnya murid akan mengeluarkan kembali dan mengkonstektualisasikan pelajaran yang dihafalnya sehingga dalam diskusi dan perdebatan murid dapat merespons, mematahkan lawan, atau memunculkan sesuatu yang baru.

3. Metode Tulisan; dianggap metode yang paling penting pada masa ini. Metode tulisan adalah pengkopian karya-karya ulama. Metode ini disamping berguna bagi proses penguasaan ilmu pengetahuan juga sangat penting artinya bagi penggandaan jumlah buku teks, karena pada masa ini belum ada mesin cetak, dengan pengkopian bukubuku maka kebutuhan terhadap teks buku sedikit teratasi.

\section{F. Penutup}

Dari paparan di atas, dapat dikemukakan beberapa kesimpulan sebagai berikut:

1. Penyelenggaraan pendidikan pada masa rasulullah tidak terlepas dari integrasi secara komprehensif berbagai kelengkapan pendidikan yaitu: metode, kurikulum/materi, evaluasi, peserta didik, lembaga, visi, misi, tujuan dan sasaran. Di masa Khulafaur-rasyidin, tidak jauh berbeda dengan masa rasulullah yang menekankan pada pengajaran baca tulis dan materi tentang ajaran Islam yang bersumber pada Al-Qur'an dan Hadis nabi.

2. Penyelenggaraan pendidikan masa Bani Umayyah sudah mengalami berbagai kemajuan karena didukung oleh sumber daya manusia yang berwawasan ilmu pengetahuan, keterampilan, keahlian teknis dan pengalaman. Pemerintahan Bani Umayyah, sangat memperhatikan pendidikan dengan menyediakan sarana dan prasarana seperti perpustakaan, madrasah, toko buku, majlis ilmu, bahkan hingga perguruan tinggi. Selain itu penyiapan guru dan para ahli dalam berbagai bidang ilmu serta biaya pendidikan gratis.

3. Masa Bani Abbasiyah merupakan puncak perkembangan ilmu dan pendidikan Islam, serta banyak didirikan institusi pendidikan mulai dari tingkat dasar, menengah hingga Perguruan Tinggi. Bagdad dijadikan sebagai pusat ilmu pengetahuan yang ramai dikunjungi. Bahkan terdapat madrasah yang paling terkenal saat itu yakni madrasah an-Nizamiyah dan 
madrasah Darul ilmi serta Baitul hikmah (perpustakaan dan pusat bukubuku). Pada masa Abbasiyah ini pula para guru mendapat gaji yang sangat tinggi bahkan mereka disekolahkan ke luar untuk menambah ilmu dan wawasan.

\section{DAFTAR PUSTAKA}

Abdullah Idi dan Toto Suharto, Revitalisasi Pendidikan Islam, (Yogyakarta: Tiara Wacana, 2006).

Abuddin Nata, H., Pendidikan Islam Perspektif Hadits. (Ciputat: UIN Jakarta Press, 2005).

Arifin, H.M., Ilmu Pendidikan Islam, (Jakarta: Bumi Aksara, 1991).

Ajid Thohir, Perkembangan Peradaban Di Kawasan Dunia Islam, (Jakarta: Raja Grafindo Persada),2004

Armai Arief, Sejarah Pertumbuhan dan Perkembangan Lembaga Pendidikan Islam Klasik, (Bandung: Penerbit Angkasa, 2005).

Badri Yatim, Sejarah Peradaban Islam Dirasah Islamiyah II, (Jakarta: Rajawali Pers), 2011.

Daradjat, Zakiyah, dkk, Ilmu Pendidikan Islam, (Jakarta: Bumi Aksara, 1996).

Harun Nasution, Pembaharuan dalam Islam: Sejarah Pemikiran dan Gerakan, (Jakarta: Bulan Bintang, 1975).

Hanun Asrohah, Sejarah Pendidikan Islam, (Jakarta : Bumi Aksara, 1997).

Hasan Asari, Menyingkap Zaman Keemasan Islam, (Bandung: Mizan, 1994).

Joesoef, Sejarah Daulah Khulafaur Rasiddin, (Medan: Bulan Bintang), 1979.

Langgulung, Hasan, Pendidikan Islam Menghadapi Abad ke-21, (Jakarta: Pustaka al-Husna, 1988).

Munawar Cholil, Kelengkaan Tarikh Nabi Muhammad Saw, (Jakarta: Bulan Bintang, 1969).
Moh. Untung Slamet, Muhammad Sang Pendidik, (Semarang: Pustaka Rizki Putera, 2005).

Mehdi Nakosteen, Konstribusi Islam atas Dunia Intelektual Barat: Deskripsi Analisis Abad Keemasan Islam, alih bahasa Joko S. Kahhar dan Supriyanto, (Surabaya: Risalah Gusti, 1995).

Makdisi, Geoge, dalam The Rise of Colleges Institutions of Learning in Islam and West, (Eidenburgh: Eidenburgh University Press, 1981).

Nasution, S., Asas-asas Kurikulum, (Jakarta: Bumi Aksara,1994).

Omar Mohammad Al-Toumy A-Syaibany, Falsafah Pendidikan Islam, (Terj.Hassan Langgulung), (Jakarta: Bulan Bintang, 1984).

Ramayulis, H., Ilmu Pendidikan Islam, (Jakarta: Kalam Mulia, 2006).

Samsul Munir Amin, Sejarah Peradaban Islam. Jakarta: Amzah, 2009

Sayyid Quthub, Konsepsi Sejarah Dalam Islam, terj. Nabhan Husein, (Jakarta: Al-Amin, tt, h).

Samsul Nizar, Sejarah Pendidikan Islam: Menelusuri Jejak Sejarah Era Rasulullah Sampai Indonesia. (Jakarta: Kencana, 2007).

Samsul Nizar, Dr., Sejarah Pendidikan Islam, Jakarta: Kencana Prenada Media Group, 1997. Soekarno, Drs., Sejarah Dan Filsafat Pendidikan Islam, (Bandung: Angkasa, 1983)

Syalabi, Sejarah Kebudayaan Islam, (Jakarta: Pustaka Al-Husna),1990

Soekarno dan Ahmad Supardi, Sejarah dan Filsafat Pendidikan Islam, (Bandung: Angkasa), 1985

Yunus, Mahmud, H., Sejarah Pendidikan Islam, (Jakarta: PT. Raja Grafindo, Persada, 2008).

Zuhairini, dkk, Sejarah Pendidikan Islam, (Jakarta: Bumi Aksara, cet.9, 2008). 
Penyelenggaraan Pendidikan Islam Jaman Klasik (di Masa Rasulullah SAW dan Era Kekhalifahan)

Rausyan Fikr. Vol. 16 No. 1 Maret 2020. ISSN. 1979-0074 e-ISSN. 9772580594187 | 30 